\title{
A CRISE FINANCEIRA E O GLOBAL SHADOW BANKING SYSTEM'
}

\author{
Marcos Antonio Macedo Cintra \\ MARYSE FARHI
}

\begin{abstract}
RESUMO
A crise financeira iniciada com a elevação da inadimplência e a desvalorização dos imóveis e dos ativos financeiros associados às hipotecas americanas de alto risco (subprime) recolocou em debate a arquitetura do sistema financeiro americano e internacional, seus potenciais riscos sistêmicos e seus mecanismos de supervisão e regulação. Uma grande variedade de instituições financeiras frouxamente reguladas e displicentemente supervisionadas passou a constituir a contraparte da transferência de riscos de crédito do sistema bancário e a carregar riscos crescentes. $\mathrm{O}$ artigo procura discutir a interação dessas instituições financeiras, incluindo algumas características do principal palco dessa interação - os mercados de balcão - e a utilização de determinadas inovações financeiras que amplificaram a crise. Dada a complexidade e opacidade dessas instituições e mercados, busca ainda explicitar a necessidade de aperfeiçoamentos na sua regulação e supervisão.
\end{abstract}

PALAVRAS-CHAVE: crise econômica; capitalismo financeiro; crédito; sistema bancário.

\section{SUMMARY}

The financial crisis triggered by increasing default rate, real estate devaluation and financial asset depreciation combined with U.S. subprime mortgages brought about the debate over the framework of the U.S. and international financial systems, their potential systemic risks, and their regulatory and supervisory mechanisms. A great variety of financial institutions which were poorly regulated and badly supervised changed into the counterpart of the credit risk transfer from the banking system and started to hold increasing risks. This paper deals with the interaction of these financial institutions, including a description of some features of the major stage in this process - the so-called over-the-counter (OTC) market - and the use of financial innovations which amplified the crisis. It also aims to clarify the need for improvements in terms of regulation and supervision considering the complexity and opacity of these institutions and markets.

KEYWORDS: economic crisis; capitalism; credit; banking system.

[1] Artigo elaborado com informações disponíveis até 20 de novembro de 2008. Os autores agradecem os comentários e sugestões da equipe do Cecon - Ricardo Carneiro, Antonio C. M.e Silva, Daniela Prates, Francisco Lopreato, André Biancareli, Emerson Marçal e Eliana Ribeiro -, de M. Cristina Penido, de José Carlos Braga, de Rafael Cagnin e de André Scherer.

\section{INTRODUÇÃO}

A crise financeira iniciada nos Estados Unidos, em meados de 2007, em decorrência da elevação da inadimplência e da desvalorização dos imóveis e dos ativos financeiros associados às hipotecas americanas de alto risco (subprime), tem renovado os questionamentos sobre a arquitetura contemporânea do sistema financeiro americano e internacional, seus potenciais riscos sistêmicos e seus mecanismos de supervisão e regulação. Essa arquitetura específica transformou uma crise de crédito clássica em uma crise 
financeira e bancária de imensas proporções, que lhe conferiu um caráter sistêmico. Numa crise de crédito clássica, o somatório dos prejuízos potenciais (correspondente aos empréstimos concedidos com baixo nível de garantias) já seria conhecido. Na atual configuração dos sistemas financeiros, os derivativos de crédito e os produtos estruturados lastreados em diferentes operações de crédito replicaram e multiplicaram tais prejuízos por um fator desconhecido e redistribuíram, globalmente, os riscos deles decorrentes para uma grande variedade de instituições financeiras. Passado mais de um ano da eclosão da crise, continuou sendo impossível mensurar as perdas e determinar sua distribuição. Isso provocou profunda desconfiança dos agentes e constituiu um potente combustível para a propagação da crise. Por essa razão a liquidez interbancária persistiu restrita, apesar das contínuas e volumosas injeções de liquidez pelas autoridades monetárias.

O desenrolar da crise pôs em questão a sobrevivência de diversas instituições financeiras e colocou em xeque esta arquitetura financeira, bem como os princípios básicos do sistema de regulação e supervisão bancária e financeira. Este desenrolar trouxe alguma luz a diversos aspectos desta arquitetura, antes envoltos em sombra, o que possibilitou elucidar sua efetiva configuração. O principal desses aspectos consiste na interação entre bancos universais e as demais instituições financeiras, que se deu, sobretudo, nos opacos mercados de balcão. Os bancos buscaram diversas formas de retirar os riscos de crédito de seus balanços com o objetivo de ampliar suas operações sem ter de reservar os coeficientes de capital requeridos pelos Acordos de Basiléia.

Fizeram isso de diversas formas: adquirindo proteção contra os riscos de crédito nos mercados de derivativos, emitindo títulos de securitização de créditos com rendimento atrelado aos reembolsos devidos pelos tomadores de empréstimos e criando diversos vé́culos especiais de investimento (Special Investments Vehicles ou SIV), conduits ou SIV-lites. Mas somente puderam fazê-lo porque outros agentes se dispuseram a assumir a contraparte dessas operações, ou seja, assumir esses riscos contra um retorno que, à época, parecia elevado.

Esses agentes formaram o chamado global shadow banking system ("sistema bancário global na sombra" ou paralelo). Um conjunto de instituições que funcionava como banco, sem sê-lo, captando recursos no curto prazo, operando altamente alavancadas e investindo em ativos de longo prazo e ilíquidos. Mas, diferentemente dos bancos, eram displicentemente reguladas e supervisionadas, sem reservas de capital, sem acesso aos seguros de depósitos, às operações de redesconto e às linhas de empréstimos de última instância dos bancos centrais. Dessa forma, eram muito vulneráveis, seja a uma corrida dos investidores (saque dos recursos ou desconfiança dos aplicadores nos 
[2] Em função das limitações do escopo, não será efetuada uma abordagem teórica das inovações financeiras e institucionais, nem será realizada uma análise da dinâmica da crise, por meio dos processos de inflação e de deflação dos ativos mobiliários e financeiros, característicos dos ciclos finance-led. Para essas discussões, ver, entre outros, Minsky, Hyman P. Stabilizing an unstable economy (New Haven: Yale University Press, 1986); Coutinho, Luciano G. e Belluzzo, Luiz G. M. "Desenvolvimento e estabilização sob finanças globalizadas" (Economia e Sociedade, n 7, Campinas: IE/Unicamp, 1996, pp. 12954); Aglietta, M. Macroeconomia financeira (2 vols. São Paulo: Edições Loyola, 2004); Kregel,Jan. “Minsky's cushions of safety: systemic risk and the crisis in the U.S. subprime mortgage market" (Public Policy Brief No. 93. The Levy Economics Institute of Bard College, January 2008 [Disponível em 〈www.levy.org〉, acessado em 24/11/2008]); Guttmann, Robert e Plihon, Dominique. Consumer debt at the center of finance-led capitalism (Paris, jan. 2008 [mimeo]); Freitas, M. Cristina P. de e Cintra, Marcos A. M. "Inflação e deflação de ativos a partir do mercado imobiliário americano" (Revista de Economia Política, vol. 28, $\mathrm{n}^{\circ} 3$ (111), São Paulo, Editora 34, jul-set. 2008 [Disponível em 〈www.rep.org.br〉, acessado em 24/11/2008]); e Aglietta, M. e outros. De la crise financière à l'enjeu d'une meilleure évaluation des crédits structurés (Paris: Ouest la Défense/ EconomiX et Cepii, Avril 2008).

[3] McCulley, Paul. "Teton reflections". Global Central Bank Focus, ago-set. 2007 [Disponível em <www.pimco.com/LeftNav/ Featured+Market+Commentary/ $\mathrm{FF} / 2007 / \mathrm{GCBF}+$ August-+Sep tember+2007.htm >].

[4] Cintra, M.A. M.e Prates, Daniela M. Basel II in question: the unfolding of the US real estate crisis. Paper preparado para o Workshop on Financial Liberalization and Global Governance, Rio de Janeiro, 8 e 9 de maio de 2008. Evento organizado pelo IBase e pela Fundação Ford [Disponível em 〈www.ibase.org.br〉] e Freitas, Jean T. Estabilidade financeira em países em desenvolvimento e Acordos de Basiléia. Campinas: dissertação de mestrado, IE/Unicamp, 2008. mercados de curto prazo), seja a desequilíbrios patrimoniais (desvalorização dos ativos em face dos passivos).

Este artigo procura discutir a interação entre as distintas instituições financeiras, incluindo algumas características do principal palco dessa interação - os mercados de balcão - e a utilização de determinadas inovações financeiras que acabaram amplificando a crise. $\mathrm{O}$ artigo está organizado em quatro seções, após esta introdução. Na primeira seção, apresenta-se a configuração do global shadow banking system. Na segunda seção, discute-se a desintegração de várias dessas instituições complexas e obscuras. Na terceira seção, analisa-se a opaca teia de inter-relações do sistema bancário com o "sistema financeiro paralelo", com ênfase nos mercados de balcão. Na quarta seção, procura-se indicar rapidamente as possíveis repercussões do encolhimento forçado do "sistema financeiro na sombra" e o sentido dos aperfeiçoamentos nas estruturas de regulação e supervisão².

\section{OS PARTICIPANTES DO GLOBAL SHADOW BANKING SYSTEM}

Segundo McCulley3, diretor executivo da maior gestora de recursos do mundo, a Pimco, o global shadow banking system inclui todos os agentes envolvidos em empréstimos alavancados que não têm (ou não tinham, pela norma vigente antes da eclosão da crise) acesso aos seguros de depósitos e/ou às operações de redesconto dos bancos centrais. Esses agentes tampouco estão sujeitos às normas prudenciais dos Acordos de Basiléia4. Nessa definição, enquadram-se os grandes bancos de investimentos independentes (brokers-dealers)s, os hedgefunds, os fundos de investimentos, os fundos private equity, os diferentes veículos especiais de investimento, os fundos de pensão $e$ as seguradoras. Nos Estados Unidos, ainda se somam os bancos regionais especializados em crédito hipotecário (que não têm acesso ao redesconto) e as agências quase-públicas (Fannie Mae e Freddie $\mathrm{Mac})$, criadas com o propósito de prover liquidez ao mercado imobiliário americano.

Os bancos concedem empréstimos com os recursos que recebem de seus depositantes, e com seu capital próprio. Mas, sobretudo, os bancos criam depósitos - moeda bancária escritural - ao conceder crédito ${ }^{6}$. Passaram também a emitir dívidas para obter recursos e conceder novos financiamentos 7 . Em geral, os empréstimos concedidos possuem prazos mais longos do que os depósitos ou as dívidas. Em decorrência da criação de depósitos e do descasamento de prazos, o sistema tende a ser altamente instável, sujeito a processos de euforia ou pessimismo e a corridas bancárias. Por esta razão, foram desenvolvidas instituições para garantir os depósitos, para atuar como 
"emprestadoras de última instância", para regular e supervisionar o sistema, de forma a assegurar que os bancos sempre detenham ativos suficientes para fazer frente aos movimentos de saques.

Nas últimas décadas, verificaram-se três movimentos simultâneos ecomplementares. Em primeiro lugar, os bancos comerciais, submetidos à regulação prudencial e ao acirramento da concorrência, aumentaram extraordinariamente o volume de crédito concedido. Para fazêlo, tiveram de retirar parte dos ativos (e, portanto, dos riscos) de seus balanços, uma vez que o capital próprio (reservas) era insuficiente para atender as exigências dos Acordos de Basiléia. Dessa forma, deixaram de atuar como fornecedores de crédito e assumiram o papel crescente de intermediadores de recursos em troca de comissões. Romperam, por conseguinte, as relações diretas, antes existentes, com os tomadores de crédito que costumavam ser monitoradas de perto, pois serviam de "indicador antecedente" de riscos de inadimplência. Em segundo lugar, os bancos passaram a administrar fundos de investimentos, oferecer serviços de gestão de ativos por meio de seus vários departamentos, fornecer seguros financeiros (hedge) como dealers no mercado de derivativos e ofertar linhas de crédito nas emissões de commercial paper e outros títulos de dívida no mercado de capitais ${ }^{8}$. Em terceiro lugar, uma grande variedade de instituições evoluiu no sentido de desempenhar um papel semelhante ao dos bancos comerciais sem estarem incluídas na estrutura regulatória existentee, portanto, sem disporem das requeridas reservas em capital.

$\mathrm{Na}$ busca de instrumentos para retirar os riscos de crédito de seus balanços, os bancos sujeitos à regulação também estiveram na origem do surgimento e da forte expansão dos derivativos de crédito (CDS), por meio dos quais podem comprar proteção para os riscos de crédito de suas carteiras de empréstimos. Valeram-se, igualmente, dos chamados "produtos estruturados", instrumentos resultantes da combinação entre um título representativo de um crédito - debêntures, bônus, títulos de crédito negociáveis, hipotecas, dívida de cartão de crédito etc. - e o conjunto dos derivativos financeiros (futuros, termo, swaps, opções e derivativos de crédito) qualquer que seja seu ativo subjacente. Num primeiro momento, os bancos empacotaram os créditos concedidos, os submeteram às agências de classificação de riscos e lançaram títulos sobre eles, com rendimentos proporcionais ao fluxo de caixa gerado pela quitação das prestações dos créditos. Os títulos estruturados eram divididos em diversas tranches com riscos e retornos diferenciados. A estrutura de distribuição dos juros ficou conhecida como "queda d'água" (interest waterfall), porque a água tem de encher o primeiro reservatório ou tranche mais sênior, para posteriormente começar a preencher os outros (mezzanine e equity). A porção mais arriscada dentre elas (equity) - a que assume os riscos de
[5] Operam como intermediários entre um comprador e um vendedor, geralmente cobrando uma comissão, $e$ atuam por sua própria conta e risco em negociações de valores mobiliários.

[6] Keynes, J. M. Treatise on money. The collected writings of John Maynard Keynes, vols. 5 e 6. Organizado por D. E. Moggridge, D. E. Londres: Macmillan, 1971 [1930].

[7] Chick, V. "A evolução do sistema bancário e a teoria da poupança, do investimento e dos juros". Ensaios $F E E$, ano $15, \mathrm{n}^{\mathrm{Q}}$ 1, Porto Alegre, 1994 , pp. 9-23,

[8] Farhi, Maryse. Novos instrumentos e práticas na finança internacional. Campinas: Instituto de Economia; São Paulo: Fapesp, 2002 (Relatório de pesquisa de pós-doutorado). 
[9] Essas entidades tendem a se diferenciar pelo tamanho e composição do ativo e passivo. Em geral, os conduits tendem a ser maiores e menos arriscados, enquanto os SIV e os SIV-lites operam com alta alavancagem. Todos eles têm algum mecanismo de liquidez total ou parcial garantido pelas instituições patrocinadoras (IMF. Global financial stability report. Washington, D.C.: International Monetary Fund, abr. 2008-out. 2008).

[10] Reilly, D. e Mollenkamp, C. "Conduits' in need of a fix". The Wall Street Journal, 30/08/2007.

[11] Kregel, op. cit.; Guttmann e Plihon, op.cit.; e Freitas e Cintra, op. cit.

[12] Blackburn, Robin. "The subprime crisis". New Left Review, nำ50, Londres, mar.-apr. 2008, p. 90. inadimplência iniciais e que recebeu o nome de lixo tóxico (toxic waste) - acabou muito freqüentemente ficando entre os ativos dos veículos especiais de investimento. Essas diversas pessoas jurídicas - Special Investment Vhicles (SIV), conduits ou SIV-lites ${ }^{9}$ - , criadas para adquirir os títulos estruturados, com recursos provenientes da emissão de títulos de crédito de curto prazo (asset-backed commercial paper), não eram tecnicamente propriedades dos bancos nem seus resultados figuravam nos balanços, constituindo parte relevante do global shadow banking system junto com diversos outros intermediários financeiros. Dessa forma, os bancos universais obtinham mais recursos, além de receitas (taxas, comissões etc.), que lhes permitiram conceder novos créditos e elevar seus lucros, num processo de crescente alavancagem. Num segundo momento, passaram a emitir versões "sintéticas" desses instrumentos com lastro em derivativos de crédito e não em créditos concedidos.

Não estando habilitados a obter recursos de depositantes, os SIV e os outros intermediários financeiros foram buscá-los nos mercados de capitais, sobretudo, emitindo títulos de curto prazo (commercial papers), comprados pelos fundos de investimentos (money market mutualfunds). Segundo o Wall Street Journal, os SIV tinham emitido US\$ 1,5 trilhão em commercial papers, até meados de $2007^{10}$. Não podendo criar moeda ao conceder crédito diretamente, eles utilizaram esses recursos de curto prazo para assumir a contraparte das operações dos bancos, seja no mercado de derivativos, vendendo proteção contra riscos de crédito, seja nos produtos estruturados, adquirindo os títulos emitidos pelos bancos com rentabilidade vinculada ao reembolso dos créditos que esses concederam. Tornaram-se, dessa forma, participantes do mercado de crédito, obtendo recursos de curto prazo com os quais financiavam créditos de longo prazo (hipotecas de trinta anos, por exemplo), atuando como quase-bancos ${ }^{11}$.

Além dos SIV, uma grande variedade de instituições financeiras optou por participar do global shadow banking system. As principais foram os grandes bancos de investimentos (brokers-dealers), seguidos pelos hedge funds e outros investidores institucionais, sobretudo as seguradoras, os fundos de pensão e as Government Sponsored Enterprises (GSE). Os bancos de investimento multiplicaram os hedge funds sob sua administração, abrindo espaço em suas carteiras para produtos e ativos de maior risco e montaram estruturas altamente alavancadas. Da mesma forma, os bancos universais também passaram a patrocinar hedge funds, fornecendo-lhes crédito para suas operações (inclusive compra de "produtos estruturados"), bem como copiando suas estratégias de negócios. Como afirma Blackburn"12: "os bancos de Wall Street não somente patrocinam hedge funds, mas cada vez mais passam a se parecer com eles 
à medida que usam sua posição de intermediários primários [prime brokers] para alavancar suas apostas e buscar arbitragens" ${ }^{13}$. O papel dos hedge funds é crucial, pois eles aparecem em diversas pontas do processo de alavancagem e difusão de ativos financeiros (CDO, CDS etc.). Ademais, são os agentes mais difíceis de serem colocados sob o arcabouço regulatório dos bancos centrais. Ou seja, os hedge funds são os agentes mais desregulamentados (e, portanto, mais shadow), ao mesmo tempo em que são extremamente dependentes da liquidez bancária e contribuem para ampliar o risco sistêmico ${ }^{14}$. Por sua vez, as GSE, com garantia implícita do setor público, representaram o espelho dos veículos "fora de balanço" do setor financeiro privado altamente alavancado ${ }^{15}$. Belluzzo sublinhou as razões e o alcance dessa opção estratégica dos integrantes do global shadow banking system: "em um ambiente de estabilidade e de rendimentos em queda, a busca de ganhos mais alentados levou aos píncaros as relações entre o valor dos ativos carregados nas carteiras e o capital próprio das instituições" 16 .

Também deve ser salientado o papel das agências de classificação de riscos (rating) na constituição do global shadow banking system. Essas agências tiveram um crescimento acelerado e registraram forte elevação de lucros com a expansão da securitização dos ativos de crédito (asset backed securities). Ao auxiliar as instituições financeiras na montagem dos "pacotes de crédito" que lastreavam os títulos securitizados de forma a garantir a melhor classificação possível, as agências tiveram participação relevante na criação do mito que ativos de crédito bancário podiam ser precificados e negociados como sendo de "baixo risco" em mercados secundários. Ademais, elas incorreram em sério conflito de interesses na medida em que parte substancial de seus rendimentos advinha dessas atividades.

\section{O DESMANCHE DO GLOBAL SHADOW BANKING SYSTEM}

Entre junho de 2007 e novembro de 2008 , houve vários momentos mais agudos da crise, com repercussões acentuadas nos mercados interbancários globais ${ }^{17}$. Esses momentos ficaram explícitos no comportamento da chamada TED spread - a diferença entre a taxa dos títulos do Tesouro americano de três meses (no mercado secundário) e a taxa Libor (London Interbank Offered Rate) para os depósitos em eurodólar de três meses -, referência internacional para empréstimos entre bancos, estimados em US\$23,3 trilhões, em março de 2008 , pelo Bank for International Settlements (BIS) (ver Gráfico 1). Apesar da acentuada queda da taxa básica de juros americana e da redução conjunta de taxas de juros das principais economias desenvolvidas em outubro e novembro de 2008 , o spread entre títulos de curto prazo
[13] Para maiores discussões sobre a emulação das estratégias dos hedge funds pelos bancos universais, Cintra, Marcos A. M.; Cagnin, Rafael F. "Evolução da estrutura e da dinâmica das finanças norte-americanas". Econômica, v.9, $\mathrm{n}^{\mathrm{Q}}$ 1, Rio de Janeiro, p.89-131, dezembro de 2007. De acordo com a Economist: "And funds-ofhedge-funds, which act as intermediaries for private banks, some institutions and individuals who are merely affluent, have become hugely important. They supply more than $46 \%$ of industry assets under management, compared with only $5 \%$ in 1990" (The Economist. "The incredible shrinking funds". Londres, 23/10/2008 [Disponível em <www. economist.com/finance/displaystory.cfm?story_id=12465372 , acessado em 24/11/2008]).

[14] Aglietta, Michel e Rigot, Sandra. La réglementation des hedge funds face à la crise financière: une contribution au débat.Paris: Ouestla Défense/EconomiX et Cepii, 2008 (mimeo).

[15] As GSE também têm presença ativa nos mercados de swaps de taxas de juros e nos derivativos de crédito (ver <www.ofheo.gov/Media/ Archive/docs/reports/sysrisk.pdf> e The Economist, "End of illusions", 17/07/2008).

[16] Belluzzo, Luiz G. M. "Salvação de moribundos". Carta Capital, ano XIV, nº 505. São Paulo, 23/07/2008, pp. 54-55.

[17] Para uma cronologia mais detalhada dos principais fatos relacionados com a crise, ver, entre outros, BIS. 78 th Annual Report. Basle: Bank for International Settlements, June 30 2008, 109-110; Borio, C. The financial turmoil of 2007-?: a preliminary assessment and some policy considerations. BIS Working Papers, $\mathrm{n}^{2} 251$. Basle: BIS/Monetary and Economic Department, mar. 2008; e Fundap. Panorama e perspectiva das economias avançadas: sob o signo da crise. São Paulo, Grupo de Conjuntura da Fundap, 05/11/2008 [Disponível em <www.fundap.sp.gov.br/debatesfundap/pdf/conjuntura/Panorama e_perspectivas_das_economias_ avan $\% \mathrm{C}_{3} \%$ A7adas.pdf $>$, acessado em 24/11/2008]). 
[18] Salienta-se que o Wall Street Journal levantou a suspeita de que algunsbancos-Citigroup,JPMorgan Chase, UBS, WestLB e HBOS PLC estariam informando seus custos de captação para o cálculo da Libor significativamente menores do que outras medidas do mercado, como o seguro contra inadimplência (CDS). Esses bancos são membros do grupo de dezesseis instituições financeiras cujas taxas são usadas para definir a Libor em dólares. Segundo o WSJ, "entre janeiro e abril, com o temor crescente de quebra de bancos, as duas medidas começaram a divergir e as taxas reportadas para a Libor deixaram de refletir o aumento no custo dos seguros de inadimplência. [...] Uma possível explicação para essa diferença é que os bancos reportaram taxas de captações inferiores às reais" (Mollenkamp, Carrick e Whitehouse, Mark. "Análise corrobora crença de que Libor pode estar menos precisa". Valor Online, São Paulo, 29/05/2008 (publicado originalmente em The Wall Street Journal, 2008).

[19] McCulley, Paul. Comments on housing and the monetary transmission mechanism, set. 2007 [Disponível em <www.econbrowser.com/ar chives/2007/o9/comments_on_ hou.html>, acessado em 24/11/ 2008].

[20] Kedrosky, P. The First non-bank bank run, 03/09/2007 [Disponível em <http://paul.kedrosky.com/ archives/2007/09/03/the_first _nonba.html>, acessado em 24/11/ 2008].

[21] Até o momento, os hedge funds, as seguradoras e os fundos de pensão não tiveram acesso a essas operações. americano e a taxa Libor ${ }^{18}$ persistiu em patamar elevado. Por um lado, manteve-se elevada incerteza no mercado interbancário. A falência do banco de investimento Lehman Brothers, em 15 de setembro, acarretou a paralisação das operações interbancárias, e a desconfiança dos investidores nos sistemas financeiros se espalhou, resultando em movimentos de pânico nos mercados de ações, de câmbio, de derivativos e de crédito, em âmbito global. Por outro lado, ampliou-se a preferência pelos títulos do Tesouro americano, os ativos de última instância do sistema monetário global, ainda sob o comando do Estado americano, provocando um movimento de fuga para o dólar, a despeito de Wall Street ser um dos epicentros da crise. Em 20 de novembro de 2008 , com o aumento da demanda, o rendimento sobre os títulos do Tesouro americano de três meses caiu para $0,01 \%$.

Nesse período, as instituições financeiras não-bancárias sofreram de uma verdadeira "corrida bancária" contra o global shadow banking system na expressão de McCulley'19, ou de uma "corrida bancária contra não-bancos" segundo Kedroski ${ }^{20}$. Em movimentos reveladores da importância que o global shadow banking system adquiriu, o Federal Reserve e o Tesouro americano tiveram de estender a diversas dessas instituições (bancos de investimentose GSE) o acesso às operações de redesconto - com a aceitação de títulos lastreados em crédito hipotecário e outros - e a criação de linhas de crédito aos money marketmutual funds ${ }^{21}$. O Banco da Inglaterra também adotou medidas semelhantes através de operações de swaps. Entretanto, essas medidas revelaram-se insuficientes para conter o "desmanche" do global shadow banking system. Nesse processo, as instituições, buscando sobreviver, venderam avidamente os ativos para os quais ainda existia mercado, provocando acentuada desvalorização de seus preços.

\section{Gráfico 1}

TED Spread - Prêmio de Risco entre títulos de curto prazo americano e taxa Libor (pontos percentuais)

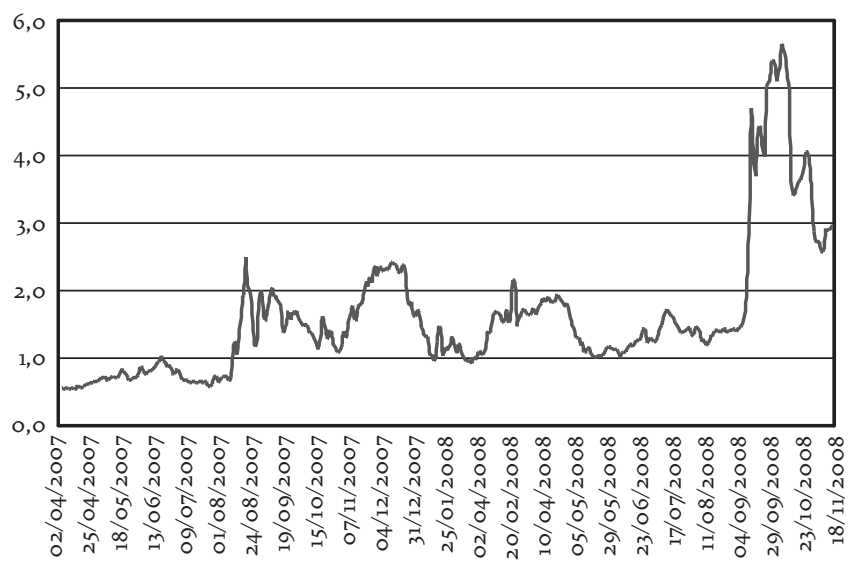

Fonte: Federal Reserve. Disponível em 〈www.federalreserve.gov/releases/h15/data.htm〉, acessado em $25 / 22 / 2008$. 
Sem dispor de reservas de capital, com ativos cuja liquidez desapareceu desde a eclosão da crise em junho de 2007 - fazendo com que seu preço deixasse de ter cotação - e confrontados ao expressivo encolhimento de sua fonte de funding, os grandes bancos de investimentos americanos simplesmente deixaram de existir. Em março de 2008 , a falência do quinto maior banco de investimentos americano somente tinha sido evitada pela intervenção e pelas garantias de US \$29 bilhões ofertadas pelo Federal Reserve para sua compra com grande desvalorização pelo JP Morgan/Chase (US \$ 10 por ação, contra uma cotação de US $\$ 170$, um ano antes). A recusa das autoridades monetárias americanas em impedir a falência do Lehman Brothers ${ }^{22}$ desencadeou a compra do Merrill Lynch pelo Bank of America e o Goldman Sachs e o Morgan Stanley obtiveram autorização para se transformar em holding financeiras (financial holding companies), sujeitas às normas de Basiléia, à supervisão do Federal Reserve e com amplo acesso às operações de redesconto das autoridades monetárias.

As instituições especializadas em crédito hipotecário sofreram fortes abalos tanto nos Estados Unidos como na Europa. A primeira corrida bancária na Inglaterra desde 1860 atingiu o banco Northern Rock, que tomava recursos a curto prazo (a cada três meses) no interbancário, para emprestá-los a longo prazo (em média, vinte anos), aos compradores de imóveis ${ }^{23}$. Com a maior aversão ao risco, as instituições financeiras cortaram suas linhas de crédito, que acabou nacionalizado (após receber US $\$ 98,3$ bilhões do Banco da Inglaterra), mesmo destino do banco especializado em créditos imobiliários e hipotecas Bradford \& Bingley (parte adquirido pelo Santander). Nos Estados Unidos, essas instituições especializadas em crédito hipotecário são formadas por um conjunto de bancos regionais. Eles recebem depósitos e, portanto, têm garantias do Federal Deposit Insurance Corp. (FIDC), mas não têm acesso ao redesconto do Federal Reserve. Em 11 de julho de 2008, o IndyMacBank sofreu intervenção do FIDC. Em decorrência de seu colapso, dois efeitos mais imediatos foram registrados:a) os depositantes no sistema bancário americano com depósitos superiores ao limite garantido pelo FDIC procuraram redistribuí-los entre diversos bancos; $b$ ) os temores de investidores e depositantes se alastraram para outras instituições do mesmo tipo, provocando várias novas falências ${ }^{24}$. O maior banco desse grupo, Washington Mutual, teve sua falência decretada em setembro de 2008. Parte de seus ativos foi adquirida do FDIC pelo banco JPMorgan/Chase.

A acentuada perda de confiança nas instituições com ativos imobiliários atingiu igualmente as duas grandes agências quase-públicas, criadas com o propósito de prover liquidez ao mercado imobiliário americano, a Federal National Mortgage Association (Fannie Mae) e a Federal Home Loan Mortgage Association (Freddie Mac) ${ }^{25}$. Essas
[22] Segundo L. C. Mendonça de Barros: "Quando quebrou, obancode investimento Lehman Brothers tinha US\$ 650 bilhões em compromissos, contra um capital de US $\$ 20$ bilhões" ("Muito pouco, muito tarde...". Folha de S.Paulo, 19/09/2008, p. B2). Mas verificou-se a posteriori que a sua falência teve efeitos nefastos, acentuando as incertezas e o empoçamento de liquidez. Ver, por exemplo, "Lehman's demise triggered cash crunch around globe" (The Wall Street Journal, 29/10/2008). O fato de o Tesouro americano ter, após várias peripécias, aceitado recapitalizar os bancos, a exemplo da Comunidade Européia, tem sido visto como a confissão deste equívoco.

[23] Ndong, Sonia O.e Scialom, Laurence. Northern Rock: the anatomy of a crisis - the prudential lessons. Apresentado no North American Economic andFinancialAssociation Conference, Honolulu, jun-jul. 2008 (mimeo).

[24] As garantias do FDIC que se estendiam até US $\$ 100 \mathrm{mil}$ por conta foram elevadas para US $\$ 250$ mil pelo chamado "Plano Paulson", aprovado pelo Congresso americano no início de outubro de 2008 .

[25] Após a crise de 1982, o sistema de financiamento imobiliário americano tem sido ancorado por quatro instituições, além dos bancos hipotecários e das instituições de poupança (S\&L): Federal Housing Administration (FHA), Government National Mortgage Association (Ginnie Mae), Federal National Mortgage Association (Fannie Mae) e Federal Home Loan Mortgage Corporation (Freddie Mac). Todo o sistema foi construído por garantias públicas diretas ou indiretas. Para maiores informações sobre o sistema financeiro imobiliário americano, ver Cagnin, Rafael F.O mercado imobiliário e a recuperação econômica dos Estados Unidos após 2002 (Campinas: dissertação de mestrado, IE/Unicamp, 2007). 
[26] Torres Filho, Ernani T. e Borça Jr., Gilberto R. "A crise do subprime ainda não acabou". Visão do Desenvolvimento, $\mathrm{n}^{\circ}$ 50. Rio de Janeiro: BNDES, 14/07/2008 [Disponível em (www.bndes.gov.br/conhecimento/ visao/visao_5o.pdf $>$, acessado em 24/11/2008].

[27] Para maiores informações, ver 〈www.fanniemae.com/media/pdf/ webcast/o80808transcript.pdf $\rangle$, acessado em 24/11/2008.

[28] De acordo com o Tesouro americano, os maiores detentores das dívidas das agências americanas eram China e Japão. companhias privadas, com ações negociadas em Bolsa de Valores, mas consideradas como "patrocinadas pelo governo" (Government Sponsored Enterprises - GSE), conseguiam se financiar a um custo bastante próximo ao do Tesouro americano (T-bonds) e, simultaneamente, operar de forma muito mais alavancada que outras instituições financeiras, sustentando um elevado endividamento - Fannie Mae tinha uma dívida total de US $\$ 800$ bilhões e Freddie Mac, de US $\$ 740$ bilhões - com um patrimônio conjunto de apenas US $\$ 71$ bilhões. As duas companhias carregavam (por meio da emissão de dívida) ou deram garantias a títulos hipotecários (RMBS) no valor de US $\$ 4,7$ trilhões, o que representava $32 \%$ dos créditos hipotecários nos Estados Unidos (US $\$ 14,8$ trilhões) e equivale a $33 \%$ do Produto Interno Bruto (PIB), estimado em US $\$ 14,3$ trilhões em junho de 2008 (ver Tabela 1).

Com a queda do preço dos imóveis, dados em garantias dos empréstimos, que passaram a valer menos do que as dívidas (hipotecas)e a duplicação no patamar de inadimplência, as empresas ficaram diante da possibilidade de insolvência (desequilíbrio patrimonial), ou pelo menos sem capital para continuar operando ${ }^{26}$. A inadimplência das hipotecas subprime em sua carteira respondeu por cerca de $2 \%$ das perdas das agências e as hipotecas Alt-A (requerem menor documentação), cerca de 50\% ${ }^{27}$. Em 30 de julho de 2008 , o Congresso americano autorizou o Tesouro a injetar US $\$ 100$ bilhões em cada uma das instituições e permitiu o refinanciamento de até US $\$ 300$ bilhões de empréstimos imobiliários, para manteros proprietários em suas casas e conter as execuções de hipotecas (foreclosures) e a deflação nos preços dos imóveis.

A inédita ação se explica pela magnitude dos passivos dessas companhias e pelo fato de parte significativa de seus títulos ter sido adquirido por bancos centrais estrangeiros. Em junho de 2008 , a dívida total das agências federais americanas detida por estrangeiros somava US $\$ 1,6$ trilhão, sendo US $\$$ 1,1 trilhão em portfólios de credores oficiais e US $\$ 546,7$ bilhões de credores privados (ver Tabela 2) ${ }^{28}$. Em outras palavras, títulos emitidos pela Fannie Mae e pela Freddie Mac foram considerados pelos gestores das reservas internacionais como tão "sem riscos" quanto os títulos do Tesouro americano(US \$ 1,8 trilhão), com a vantagem de oferecer rendimentos um pouco mais elevados.

É importante relembrar que os primeiros sinais da eclosão da crise atingiram os hedge funds. Entre junho e agosto de 2007, diversos hedge funds geridos por bancos comerciais e de investimento anunciaram pesadas perdas com ativos garantidos por hipotecas subprime e foram fechados, mas a sequiência dos acontecimentos foi menos destrutiva para essas instituições financeiras que administram ativos estimados em US $\$ 2$ trilhões e operam com grau de alavancagem extremamente elevado. Alguns fatores podem explicar este grau relativo de "sobrevivência". 


\begin{tabular}{|c|c|c|c|c|c|}
\hline & 2004 & 2005 & 2006 & 2007 & 2008 (a) \\
\hline Total & 10.668 & 12.101 & 13.512 & 14.603 & 14.804 \\
\hline \multicolumn{6}{|l|}{ Por tipo de propriedade } \\
\hline Residencial (1 a 4 famílias) & 8.273 & 9.379 & 10.452 & 11.158 & 11.254 \\
\hline Residencial (multifamiliar) & 618 & 688 & 741 & 837 & 875 \\
\hline Comercial & 1.680 & 1.933 & 2.210 & 2.490 & 2.565 \\
\hline Rural & 97 & 102 & 109 & 117 & 109 \\
\hline \multicolumn{6}{|l|}{ Por tipo de detentor } \\
\hline Principais instituições financeiras & 3.926 & 4.396 & 4.781 & 5.067 & 5.114 \\
\hline Bancos comerciais & 2.596 & 2.958 & 3.403 & 3.646 & 3.662 \\
\hline Instituições de poupança e empréstimo & 1.057 & 1.153 & 1.074 & 1.095 & 1.116 \\
\hline Cias. de seguro de vida & 273 & 285 & 304 & 326 & 336 \\
\hline Agências federais & 5 & 5 & 5 & 5 & 5 \\
\hline Farmers Home Administration & 400 & 367 & 383 & 404 & 421 \\
\hline Federal Housing Admin./Dept. of Veterans Affairs & 53 & 55 & 60 & 67 & 72 \\
\hline Federal National Mortgage Association (Fannie Mae) & 61 & 61 & 66 & 80 & 88 \\
\hline Federal Land Banks & 4.834 & 5.673 & 6.575 & 7.382 & 7.549 \\
\hline Federal Home Loan Mortgage Corporation (Freddie Mac) & 441 & 405 & 410 & 443 & 510 \\
\hline Pool de Hipotecas ou Trusts (b) & 1.189 & 1.309 & 1.451 & 1.717 & 1.802 \\
\hline Government National Mortgage Association & 1.743 & 1.827 & 1.973 & 2.298 & 2.445 \\
\hline Federal Home Loan Mortgage Corporation (Freddie Mac) & 1.460 & 2.132 & 2.738 & 2.918 & 2.787 \\
\hline Federal National Mortgage Association (Fannie Mae) & 1.203 & 1.365 & 1.467 & 1.428 & 1.386 \\
\hline Private mortgage conduits (c) & 3.926 & 4.396 & 4.781 & 5.067 & 5.114 \\
\hline Indivíduos e outros (d) & 2.596 & 2.958 & 3.403 & 3.646 & 3.662 \\
\hline
\end{tabular}

Fonte:Federal Reserve,Statistical Supplementtothe Federal Reserve Bulletin, October 2008.Disponivel em «www.federalreserve.gov/pubs/supplement/2008/10/ table1_54.htm>, acessado em 25/11/2008.

Notas: a) Posição em junho de 2008 ; b) Estoque de hipotecas securitizadas (mortgage-backed securities) emitidas ou garantidas pela agência indicada; c) Inclui home equity loans securitizados; d) Outros detentores incluem mortgage companies, real estate investment trusts, state and local credit agencies, state and local retirement funds, credit unions e finance companies.

Em primeiro lugar, é preciso levar em conta o fato de grande parte dessas instituições, por serem menores, apresentar uma maior agilidade, o que lhes permitiu assumir mais rapidamente posições defensivas nos mercados. Essas posições defensivas implicaram as vendas dos ativos e a realização de novas posições "vendidas", o que colocou mais pressão em seus preços. A Securities and Exchange Commission (SEC) procurou limitar este efeito proibindo a realização de vendas a 


\section{Tabela 2}

Valor de mercado dos títulos do Tesouro e das Agências Federais detidos por estrangeiros

US\$ bilhões/em fim de período

\begin{tabular}{|c|c|c|c|c|c|c|c|}
\hline & 1980 & 1985 & 1990 & 1995 & 2000 & 2005 & 2008 (a) \\
\hline \multicolumn{8}{|l|}{ Títulos do Tesouro em mercado } \\
\hline Estoque Total & 730,0 & $1.586,6$ & $2.465,8$ & $3.608,5$ & $3 \cdot 357,8$ & $4.678,0$ & $5.250,6$ \\
\hline Estoque detido por estrangeiros & 127,4 & 226,4 & 438,4 & 816,9 & $1.021,4$ & $1.984,4$ & $2.708,2$ \\
\hline Oficial & 111,3 & 138,4 & 285,9 & 490,0 & 639,8 & $1.340,6$ & $1.843,3$ \\
\hline Privado & 16,1 & 88,0 & 152,5 & 327,0 & 381,6 & 643,8 & 865,0 \\
\hline Participação dos estrangeiros & 17,5 & 14,3 & 17,8 & 22,6 & 30,4 & 42,4 & 51,6 \\
\hline \multicolumn{8}{|l|}{ Títulos de Agências Federais } \\
\hline Estoque total & 278,3 & 628,9 & $1.445,9$ & $2.406,0$ & $4 \cdot 347,0$ & $6.158,0$ & $7.889,0$ \\
\hline Estoque detido por estrangeiros & 8,5 & 17,5 & 49,4 & 123,1 & 348,2 & $1.011,9$ & $1.650,6$ \\
\hline Oficial & 6,9 & 6,6 & 5,3 & 17,5 & 116,4 & 487,2 & $1.103,9$ \\
\hline Privado & 1,6 & 10,9 & 44,1 & 105,5 & 231,9 & 524,7 & 546,7 \\
\hline Participação dos estrangeiros & 3,1 & 2,8 & 3,4 & 5,1 & 8,0 & 16,4 & 20,9 \\
\hline \multicolumn{8}{|l|}{ Total (Tesouro e Agências) } \\
\hline Estoque total & $1.008,3$ & $2.215,5$ & $3 \cdot 911,7$ & $6.014,5$ & $7 \cdot 704,8$ & $10.836,0$ & $13.139,6$ \\
\hline Estoque detido por estrangeiros & 135,9 & 243,9 & 487,8 & 940,0 & $1.369,6$ & $2.996,3$ & $4 \cdot 358,8$ \\
\hline Participação dos estrangeiros & 13,5 & 11,0 & 12,5 & 15,6 & 17,8 & 27,7 & 33,2 \\
\hline Oficial & 87,0 & 59,5 & 59,7 & 54,0 & 55,2 & 61,0 & 67,6 \\
\hline Privado & 13,0 & 40,5 & 40,3 & 46,0 & 44,8 & 39,0 & 32,4 \\
\hline
\end{tabular}

Fonte: Federal Reserve, Flows of Fund, Table L.4 e L.107, vários números. Nota: (a) posição em junho de 2008.

[29] Ver U.S. hedge funds losses balloon <www.hedgeworld.com:80/ news/read_newsletter_aa. cgi? section $=$ ind $x \&$ story $=$ ind $x 1307$. html, acessado em 24/11/2008. descoberto de ações de diversas empresas, notadamente do conjunto das instituições financeiras. Esse movimento foi seguido pelas autoridades de supervisão dos mercados das economias desenvolvidas (como o Reino Unido).

Em segundo lugar, embora eles compartilhem a denominação genérica de hedge funds, existe uma grande diversidade nas estratégias adotadas. Essa diversidade aparece claramente em seus resultados. Segundo a publicação especializada Hedge World ${ }^{29}$ de $08 / 10 / 2008$, na média, os hedge funds tiveram perdas de $9,41 \%$ no ano, bastante inferiores às registradas, por exemplo, pelos tradicionais fundos mútuos de ações. Os maiores perdedores foram aqueles que se concentraram em operações com commodities e energia, com perdas de $20,84 \%$ no ano; enquanto os maiores ganhadores foram os que se concentraram em posições vendidas em ações e registraram lucros de $15,14 \%$ no ano, apesarda proibição temporária da SEC (e outras agências) de posições vendidas sem cobertura em ações de instituições financeiras. 
Em terceiro lugar, deve ser ressaltada uma característica própria aos hedge funds: os pedidos de resgates dos cotistas somente são possíveis em datas predeterminadas (na maior parte, nos finais de trimestres) e os reembolsos apenas três meses depois. Esta característica não os isolou do caos financeiro vivido pelas demais instituições, mas lhes concedeu um tempo suplementar para reduzir posições quando previam resgates elevados. A aceleração da crise elevou os pedidos de resgate no fim de setembro de 2008 , ocasionando nova e gigantesca rodada de desalavancagem, tornando ainda mais nebuloso o destino desses fundos. Segundo a Economist, de novembro de 2008 :

Nos próximos quadrimestres, o impacto (da crise) deverá ser brutal. Entre 1990 e o ano passado, os ativos geridos pelos hedge funds multiplicaram-se quase cinqüenta vezes para algo como US\$2 trilhões. Agora, seus executivos prevêem que os ativos podem cair 30-40\%, com os clientes correndo para a saída. O número de fundos que tinha crescido para mais de 7 mil [...] pode ser reduzido à metade.

Last but not least, as seguradoras assumiram posições relevantes no global shadow banking system. Persaud 30 já chamava a atenção para o fato de os juros baixos fazerem com que as seguradoras não pudessem mais se contentar em investir suas reservas técnicas em ativos de baixo risco para atingir o benchmark necessário ao cumprimento de suas obrigações. Para obter o rendimento necessário, elas se moveram coletivamente para graus de riscos mais elevados. Esse deslocamento das aplicações das seguradoras intensificou-se muito no período recente de "euforia". Diversas seguradoras divulgaram enormes prejuízos financeiros, algumas de porte médio faliram. O caso mais espetacular foi o da maior seguradora do mundo, a American International Group Inc. (AIG). Antes de ser socorrida pelo Federal Reserve, esta instituição tinha declarado US $\$ 321$ bilhões em perdas e baixas contábeis. Ademais, tinha assumido posição de venda de proteção contra riscos de crédito de mais de US $\$ 460$ bilhões, incluindo US $\$ 60,6$ bilhões em proteção para ativos vinculados às hipotecas subprime ${ }^{31}$. Em 16 de setembro de 2008 , o Federal Reserve concedeu um empréstimo de US $\$ 85$ bilhões à AIG, posteriormente elevado para US $\$ 150$ bilhões, cobrando juros elevados e recebendo, em garantia, ações que lhe dão o direito de ter mais de $80 \%$ do capital votante ${ }^{32}$. Segundo Morris ${ }^{33}$, a inédita ação resultou da imensa posição assumida pela AIG comovendedora de proteção no mercado de derivativos de crédito. Meses após as ações dos grandes bancos de investimento terem sofrido quedas espetaculares, as ações das companhias seguradoras passaram a ter o mesmo destino, sugerindo a possibilidade de novas falências e de um forte movimento de consolidação do setor. Acresça-se ainda que, ape-
[30] Persaud, Avinash. Where have all the risks gone. Londres: Gresham College, zoOz [Disponível em 〈www.gresham.ac.uk〉, acessado em 24/11/2008].

[31] Son, H. "AIG's loss, need for cash add to pressure on Sullivan". Bloomberg, 09/05/2008 [Disponível em <www.bloomberg.com/apps/ne ws? pid $=20601103 \&$ sid $=$ ajcZuCY 3 lvxw\&refer=news $\#$, acessado em 24/11/2008].

[32] “A.I.G.'s Bailout Terms Revealed", 30/o9/2008 [Disponível em <http://dealbook.blogs.nytimes. com/2008/og/30/aigs-bailoutterms-revealed/?ei=5070 , acessado em 25/11/2008].

[33] Morris, Charles R. "Why Paulson blinked on AIG". Washington Independent, 18/o9/2008 [Disponível em $<$ http://washingtonindependent. com/6351/why-paulson-blinked-onaig〉, acessado em 24/11/2008]. 
[34] Em 20 de novembro de 2008 , o Tesouro americano anunciou a liquidação de um fundo de investimento e de "maneira única e excepcional" o desembolso de US \$ 5,6 bilhões em fundos públicos para pagar os investidores. $\mathrm{O}$ acordo garantiu ao fundo 45 dias para continuar com a venda de seus ativos a seu valor contábil líquido ou inferior. Ao final desse período, o Tesouro "comprará todos os ativos restantes a seu valor contábil líquido" a fim de assegurar que cada investidor receba um valor correspondente ao seu investimento inicial.

[35] Onaran, Yalman. “Banks' subprime losses top $\$ 500$ Billion on writedowns (Update1)". Bloomberg, 12/08/2008. Uma das dificuldades reside na própria forma de contabilizar as perdas. Para uns, os bancos estão maquiando balanços, escondendo prejuízos atrás de fórmulas matemáticas de avaliação de ativos mais complexos e sem liquidez a preços de mercado. Para outros, os bancos não deveriam mesmo marcar a mercado todas as perdas, pois não teriam como absorvê-las com o capital disponível.

[36] IMF. Global financial stability report. Washington, D.C.: International Monetary Fund, out. 2008.

[37] Bañales, Jorge A. "Reflexos da crise imobiliária nos Estados Unidos são sentidos até hoje", Washington, o9/o8/2008 (EFE) [reprod. em UOL-Online. Disponível em <http:// economia.uol.com.br/ultnot/ efe/2008/o8/og/ult1767u126198. jhtm>, acessado em 24/11/2008].

[38] Além dos prejuízos em suas carteiras de crédito, novos problemas surgiram em função das sucessivas quedas nas cotações dos títulos que trouxeram à luz supostas falcatruas que haviam passado despercebidas na euforia dos lucros bancários. Em tempos de baixa liquidez e elevados prejuízos, investigações da SEC levaram diversos bancos a fazer acordos de dezenas de bilhões de dólares. $\mathrm{O}$ caso envolveu títulos denominados auction rate securities (ARS), instrumentos de dívida de longo prazo com juros determinados em leilão. Os bancos foram acusados de ludibriar seus clientes ao vendê-los como sendo ativos extremamente seguros, mesmo quando seu mercado simplesmente tinha deixado de existir. Até 14 sar da falta de informações confiáveis, sabe-se que, além de seu papel no global shadow banking system, a deflação de ativos afetou profundamente tanto fundos de pensão como incontáveis fundos mútuos ao redor do mundo34.

Paralelamente, os bancos universais - contrapartes do global shadow banking system - registraram prejuízos crescentes. As estimativas das perdas são incompletas e conflitantes 35 . Para o FMI ${ }^{36}$, as perdas de hipotecas e de ativos respaldados por hipotecas podem atingir a US $\$ 1,4$ trilhão. O mesmo documento aponta que essas perdas podem ser maiores ainda se as economias desenvolvidas continuarem se deteriorando. Com efeito, o pior ainda pode estar por vir. Em primeiro lugar, a inadimplência começa a se espalhar para outras formas de crédito ao consumidor, bem como a atingir devedores de crédito hipotecário considerados de menor risco que os subprime. Em segundo lugar, é preciso levar em conta que a maior parte dos empréstimos hipotecários subprime foi concedida com condições que tornavam as prestações iniciais baixas, mas que, passados um ou dois anos, subiam de forma acentuada. De acordo com o Barclays Capital, no último trimestre de 2008 , pode haver aproximadamente US $\$ 7$ bilhões em empréstimos pendentes cujas prestações serão reajustadas. O valor subirá para cerca de US $\$ 20$ bilhões no terceiro trimestre de 2009 , e no segundo trimestre de 2010 poderá atingir a US $\$ 32$ bilhões. O aumento médio dos pagamentos mensais será de $30 \%$ no início de 2009 , e poderá alcançar a $80 \%$ no final de $2011^{37}$. Em terceiro lugar, a maior fonte de potenciais prejuízos suplementares - resultado do desmanche do shadow bankingsystem - éo aguçamento do risco de contraparte nos mercados de derivativos financeiros, isto é, o risco de as instituições que aceitaram assumir os riscos de crédito dos bancos não conseguirem honrar seus compromissos. A evolução deste risco será tratada adiante.

Perante as perdas, os grandes bancos foram obrigados, repetidas vezes, a sair em busca de novos e cada vez mais custosos aportes de capitais, em particular de fundos soberanos, para reforçar seus balanços de forma a se readequar aos critérios de Basiléi $3^{38}$. Essa necessidade foi recorrente porque se manifestou, a cada vez, que os bancos teriam sido levados a reconhecer novos prejuízos. Uma das fontes de pressões por novos capitais foi a necessidade de recolocar nos balanços os ativos deslocados para os SIV, uma das entidades do global shadow banking system. Apenas para citar um exemplo, o Citigroup foi forçado a fechar seteSIVem dezembro de 2007 , assumindo US $\$ 58$ bilhões em dívidas; em 19 de novembro de 2008 , adquiriu mais US $\$ 17,4$ bilhões de outros SIV, deteriorando seu balanço. O UBS apontou que desde meados do ano de 2007 "perto de US $\$ 265$ bilhões de capital foram captados pelos bancos, dos quais US $\$ 165$ bilhões pelos bancos americanos e 
US \$ 97 bilhões por europeus"39. Ressaltou que "o setor ainda necessitaria de mais capital" e concluía que "continuar levantando capital será cada vez mais difícil em função do cansaço dos investidores [...] e do fato que novas captações terão de ser feitas através da colocação de ações" 40 . A Bloomberg, por sua vez, estimou uma injeção de capital da ordem de US \$352,9 bilhões nos cem maiores bancos universais e de investimento, até 12 de agosto de 2008. Em início de outubro, os imensos planos públicos de socorro aos bancos e a ampliação das garantias aos depósitos mostraram que tais estimativas estavam bem aquém da realidade e que os balanços dos bancos comerciais, embora mais sólidos que os dos integrantes do global shadow banking system, também estavam imensamente fragilizados.

\section{UMA TEIA OPACA DE INTER-RELACIONAMENTO FINANCEIRO INTERNACIONAL}

A arquitetura financeira desmantelada pela crise se desenvolveu ao longo das últimas décadas tendo como pano de fundo as complexas relações que se estabeleceram entre instituições financeiras nos opacos mercados de balcão. Isso ocorreu em um contexto que foi outorgada ampla liberdade de ação aos agentes financeiros. As instituições de supervisão e regulação estavam convictas de que os mecanismos de governança corporativa e os instrumentos de gestão e monitoramento dos riscos bancários haviam evoluído a tal ponto que suas decisões poderiam ser consideradas as mais apropriadas e eficientes para se evitar a ocorrência de episódios que desembocariam em risco sistêmico.

A inexistência de uma câmara de compensação bem como a ausência de normas e especificações das operações são as características comuns aos ativos negociados no mercado de balcão. Esses instrumentos são livremente negociados entre as instituições financeiras e entre estas e seus clientes, fazendo com que as posições dos participantes sejam totalmente opacas. As negociações nesses mercados acabaram formando uma extensa e intrincada teia de créditos e débitos entre as instituições financeiras. Nem os reguladores conseguem ter uma idéia dos riscos cruzados e das posições das diversas instituições financeiras.

Ademais, os produtos negociados no mercado de balcão não têm cotação oficial. Os preços são livremente acordados entre as partes e não são transparentes, uma vez que não são tornados públicos. Essa falta de transparência nos preços nos mercados de balcão, notadamente nos que apresentam baixa liquidez ou em montagens complexas e sofisticadas, pode impedir ou dificultar sua avaliação no decorrer do período em que a posição é mantida. A prática contábil de mark-tomarket (ajustar a preços de mercado), conforme as recomendações dos de agosto de 2008, alguns bancos (Citigroup, UBS, Merril Lynch etc.) se comprometeram a recomprar US\$ 48 bilhões em ARS, enquanto outros deverão seguir esses passos, colocando pressão adicional em suas reservas de capitais (Chang, Joyce. "Bancos devem recomprar US $\$ 48$ bi em ARS". Valor Econômico, 15/08/2008, p. C2 [publicado originalmente no Financial Times, Nova York]).

[39] UBS. Global banking crisis. UBS Investment Research, 01/08/2008.

[40]Ibidem. Esta obrigação decorre da aplicação dos acordos de Basiléia que restringem a proporção possível entre capital de acionistas e capital oriundo da emissão de títulos portadores de juros. 
[41] "Os melhores ativos - os 'de nível I' - são aqueles cujo preço pode ser obtido simplesmente consultando um terminal de cotações da Bloomberg, onde a cada momento ele aparece. Ativos do 'nível z' têm seus valores baseados num modelo que os relaciona a um índice de ativos similares negociados em mercados. Os valores dos ativos do 'nível 3' são simplesmente baseados em modelos nos quais não existem elementos negociados diretamente em mercados, um tipo de trabalho de adivinhação ou, em situações conturbadas, um desejo e uma prece" (Blackburn, Robin. "The subprime crisis". New Left Review, $\mathrm{n} \cong 50$, Londres, mar.-abr. 2008, p.70).

[42] Cumpre notar que as instituições financeiras apontam o mark-tomarket como parcialmente responsável pelos imensos prejuízos que registraram. Salienta-se que os planos de resgate dos Estados Unidos e da área do euro, implementados em meados de outubro de 2008 , suspenderam as regras de marcação a mercado dos ativos, que exigem que as instituições avaliem os investimentos pelos preços que eles valem caso sejam vendidos imediatamente. As mudanças permitiram que os bancos reclassifiquem alguns ativos como investimentos de longo prazo (empréstimos e recebíveis), concedendo-lhes tempo para decidir o valor dos ativos equanto perderam com a turbulência. Isso desencadeou uma imensa polêmica em que muitos apontam que tal concessão só irá provocar maior desconfiança. organismos internacionais de supervisão e regulamentação, de forma a permitir uma avaliação do valor das posições, pode não ter referência clara e ser apenas aproximativa no que se refere aos derivativos de balcão, envolvendo consultas a outros intermediários financeiros ou cálculos segundo modelos matemáticos complexos. Já durante o final da década de 1990, alguns rumorosos casos de elevados prejuízos em mercados de balcão só foram detectados pelas empresas nos seus vencimentos e não durante o decurso da operação e estiveram na origem de diversos processos judiciais contra as instituições financeiras que intermediaram as operações.

$\mathrm{Na}$ atual crise, o problema ressurgiu de forma mais aguda. No final de 2006, o Financial Accounting Standards Board (FASB), que regulamenta as informações contábeis das instituições financeiras, introduziu nova classificação dos ativos financeiros para efeito de apuração de seus preços. O nível l compreende os ativos cujos preços são formados em mercados líquidos; o nível 2 inclui os ativos cujos preços dependem de modelos com inputs baseados em preços de ativos negociados em mercados; o nível 3 refere-se a ativos cujos mercados são os menos líquidos e cujos preços só podem ser obtidos usando-se modelos matemáticos. No nível 2, encontra-se boa parte dos derivativos de balcão, enquanto os ativos lastreados em hipotecas ou outros tipos de crédito e investimentos em private equity estão no nível $3^{41}$. $\mathrm{O}$ investidor Warren Buffett declarou à revista Fortune que essas instituições "estão marcando a modelo ao invés de marcar a mercado. A recente derrocada nos mercados de dívida transformou este processo em uma marcação a mito".

As novas normas contábeis, que deveriam garantir a estabilidade e a transparência do sistema, contribuíram para aumentar sua volatilidade e falta de transparência, provocando com isso uma crise de liquidez acompanhada de uma crise de confiança. Com efeito, os ativos de nível 1 somente representavam algo próximo de $9 \%$ dos ativos totais das instituições financeiras americanas, enquanto os de níveis 2 e 3 constituíam os $91 \%$ restantes. Assim, é difícil negar que essas instituições financeiras detinham ativos pouco líquidos em excesso, que a crise financeira se encarregou de reprecificar em níveis próximos de zero ${ }^{42}$.

A elevadíssima alavancagem das instituições financeiras repousa também na negociação de derivativos financeiros. Por meio desses instrumentos que requerem um pagamento inicial baixíssimo ou, em alguns casos, nulo, as instituições financeiras tanto buscam cobertura de seus riscos de câmbio, de juros e de preços de mercado de outros ativos como especulam sobre a tendência desses preços ou efetuam operações de arbitragem. A expansão dos mercados de balcão que já ocorria num ritmo extremamente rápido, desde o final 
da década de 1980, acelerou-se mais ainda a partir do final da década de 1990, com o surgimento e intensa negociação dos derivativos de crédito. Esses mercados negociam igualmente títulos oriundos da securitização dos créditos concedidos pelos bancos comerciais combinados com algum tipo de derivativos que recebem o nome genérico de "produtos estruturados".

Uma volatilidade elevada em mercados muito alavancados pode resultar em prejuízos superiores ao patrimônio das instituições, além de levar a um repentino aumento da percepção de riscos suplementares, num montante consolidado e numa distribuição desconhecidos. As próprias características dos mecanismos de transferência de riscos introduziram novas incertezas. Não se sabe se os riscos foram diluídos entre um grande número de pequenos especuladores ou se concentrados em algumas carteiras. Dessa forma, um ano após a eclosão da crise os prejuízos persistiram incomensuráveis e sua distribuição continuou em grande parte desconhecida, contribuindo para contrair o volume de crédito (creditcrunch), manter elevadas as taxas de empréstimo, acentuar o desconforto e, por vezes, o pânico dos investidores, desvalorizando ativos mobiliários e imobiliários, além de provocar o empoçamento da liquidez nos mercados interbancários.

Nos mercados organizados, a transferência dos ganhos e perdas é organizada e garantida pelas câmaras de compensação. Nos mercados de balcão, a inexistência dessas câmaras de compensação coloca em evidência um elevado risco de inadimplência da contraparte perdedora. Dessa forma, aumentam os riscos potenciais dos derivativos de balcão em relação aos negociados em mercados organizados. A acentuada expansão, no início deste milênio, dos derivativos de crédito ampliou fortemente os riscos agregados presentes nos mercados de balcão. Esses derivativos nasceram da constatação do crescente fosso entre técnicas sofisticadas de gestão dos riscos de juros, câmbio e de mercado e dos modos mais tradicionais disponíveis para a gestão dos riscos de crédito (securitização, diversificação de carteira, garantias colaterais, limites operacionais etc.). Sabe-se que os mercados de derivativos financeiros constituem um jogo de soma zero em que as perdas de uns correspondem exatamente aos ganhos de outros, se excetuarmos os custos de transação. No agregado, só se pode ganhar, nos mercados de derivativos, os valores perdidos por outros participantes. Mas essa característica assume importância maior nos derivativos de crédito, porque neles o risco envolve o principal da operação, enquanto nos demais derivativos o risco está na margem (vender mais barato que comprou ou comprar mais caro que vendeu).

Utilizando os mecanismos já existentes de swaps, os derivativos de crédito permitiram que os bancos retirassem riscos de seus balanços, ao mesmo tempo em que as instituições financeiras do global shadow 
[43] Para maiores informações sobre os diferentes derivativos de crédito e seus modelos de precificação, ver Magalhães,Ana Laura D.P.Derivativos de crédito: análise e relação com a crise das hipotecas subprime (Campinas: monografia, IE/Unicamp, 2008) e Yokoyama, Gustavo T. Uma abordagem sobre os derivativos de crédito e sua aplicação no gerenciamento de risco de crédito. Campinas: monografia, IE/ Unicamp, 2007.

\footnotetext{
[44] Existem duas formas de agregação dos derivativos. $O$ primeiro é o valor nocional que equivale ao valor do ativo subjacente. O segundo é denominado de "valores brutos de mercado", que corresponde ao custo de substituição de todos os contratos aos preços atuais de mercado.
}

banking system passaram a ter novas formas de assumir exposição aos riscos e rendimentos do mercado de crédito. Os mais utilizados foram os swaps de inadimplência de crédito (credit default swaps, CDS) que transferem o risco de crédito entre o agente que adquire proteção e a contraparte que aceitavender proteção ${ }^{43}$. Poresse mecanismo, odetentor de uma carteira de crédito compra proteção (paga um prêmio) do vendedor de proteção. Em troca, esse assume, por um prazo predeterminado, o compromisso de efetuar o pagamento das somas combinadas nos casos especificados em contrato, que vão de inadimplência ou falência à redução da classificação de crédito ou outros eventos que possam causar queda do valor da carteira.

Não sendo "originadoras" de crédito, as instituições do global shadow banking system assumiram, sobretudo, a posição vendida nesses derivativos, pois dessa forma podiam reproduzir "sinteticamente" a exposição ao crédito e aos seus rendimentos. Os dados apurados pelo Bank for International Settlements (BIS) indicam: a) o crescimento renitente dos derivativos de balcão que, em junho de 2008 , alcançaram US $\$ 683,7$ trilhões em valores nocionais (praticamente 11 vezes o PIB mundial estimado em US $\$ 62$ trilhões) e US $\$ 20,3$ trilhões em valores brutos de substituição a preço de mercado44, ou seja, um aumento de 28,7\% em relação ao semestre anterior (ver Tabela 3); b) uma elevação extremamente acelerada dos valores nocionais e valores brutos de mercado dos CDS (derivativos de crédito), entre junho de 2007 e junho de 2008 , num período em que os negócios com produtos estruturados ligados ao crédito foram praticamente inexistentes. Os valores nocionais de CDS atingiram US $\$ 57,3$ trilhões e os valores brutos de substituição a preço de mercado, US $\$ 3,2$ trilhões.

O forte aumento nos prêmios dos CDS decorrentes da crise aparece claramente nestes dados: para um aumento de $34,6 \%$ novalor nocional dos CDS entre junho de 2007 e junho de 2008 , registrou-se uma alta de 339,9\% no seu valor bruto de substituição a preço de mercado (ver Tabela 3). Ademais, a elevação dos valores nocionais dos derivativos de crédito num período tão conturbado indica que pode ter ocorrido, alternativa ou cumulativamente, dois fenômenos: a) prêmios mais elevados atraíram novos especuladores dispostos a assumir os riscos de crédito para os quais muitos procuravam cobertura; b) diante da impossibilidade de liquidar posições antecipadamente, agentes com uma percepção de riscos mais elevada realizaram, para este fim, operações "com sinal trocado" com outras contrapartes que são contabilizadas até seu vencimento nos agregados divulgados pelo BIS.

As instituições que tinham assumido posições vendidas nos CDS amargaram altíssimos prejuízos em função da alta dos prêmios iniciada em 2007, mas que se acentuou a partir de setembro de 2008. Esses riscos oriundos dos créditos bancários às famílias e às empresas 


\begin{tabular}{|c|c|c|c|c|c|c|c|c|}
\hline \multirow[b]{2}{*}{ Instrumento } & \multicolumn{4}{|c|}{ Valor nocional } & \multicolumn{4}{|c|}{ Valor bruto de mercado } \\
\hline & $\begin{array}{c}2006 \\
\text { dez. }\end{array}$ & $\begin{array}{l}2007 \\
\text { jun. }\end{array}$ & $\begin{array}{c}2007 \\
\text { dez. }\end{array}$ & $\begin{array}{l}2008 \\
\text { jun. }\end{array}$ & $\begin{array}{c}2006 \\
\text { dez. }\end{array}$ & $\begin{array}{c}2007 \\
\text { jun. }\end{array}$ & $\begin{array}{c}2007 \\
\text { dez. }\end{array}$ & $\begin{array}{c}2008 \\
\text { jun. }\end{array}$ \\
\hline Total & 414.845 & 516.407 & 595.341 & 683.725 & 9.691 & 11.140 & 15.813 & 20.353 \\
\hline Mercado de câmbio & 40.271 & 48.645 & 56.238 & 62.983 & 1.266 & 1.345 & 1.807 & 2.262 \\
\hline Reporting dealers (a) & 15.532 & 19.173 & 21.334 & 24.845 & 438 & 455 & 594 & 782 \\
\hline Outras inst. financeiras & 16.023 & 19.144 & 24.357 & 26.775 & 521 & 557 & 806 & 995 \\
\hline Inst. não-financeiras & 8.716 & 10.329 & 10.548 & 11.362 & 307 & 333 & 407 & 484 \\
\hline Merc. de taxas de juros & 291.582 & 347.312 & 393.138 & 458.304 & 4.826 & 6.063 & 7.177 & 9.263 \\
\hline Reporting dealers (a) & 127.432 & 148.555 & 157.245 & 188.982 & 1.973 & 2.375 & 2.774 & 3.554 \\
\hline Outras inst. financeiras & 125.708 & 153.370 & 193.107 & 223.023 & 2.223 & 2.946 & 3.786 & 4.965 \\
\hline Inst. não-financeiras & 38.441 & 45.387 & 42.786 & 46.299 & 630 & 742 & 617 & 745 \\
\hline Mercado de ações & 7.488 & 8.590 & 8.469 & 10.177 & 853 & 1.116 & 1.142 & 1.146 \\
\hline Reporting dealers (a) & 2.537 & 3.118 & 3.011 & 3.479 & 290 & 405 & 398 & 376 \\
\hline Outras inst. financeiras & 4.295 & 4.473 & 4.598 & 5.496 & 452 & 549 & 578 & 616 \\
\hline Inst. não-financeiras & 656 & 999 & 861 & 1.203 & 111 & 161 & 166 & 154 \\
\hline Mercado de commodity & 7.115 & 7.567 & 8.455 & 13.229 & 667 & 636 & 1.899 & 2.209 \\
\hline Ouro & 640 & 426 & 595 & 649 & 56 & 47 & 70 & 68 \\
\hline Outras & 6.475 & 7.141 & 7.861 & 12.580 & 611 & 589 & 1.829 & 2.142 \\
\hline Derivativos de crédito & 28.650 & 42.580 & 57.894 & 57.325 & 470 & 721 & 2.002 & 3.172 \\
\hline Simples & 17.879 & 24.239 & 32.246 & 33.334 & 278 & 406 & 1.143 & 1.889 \\
\hline Múltiplo & 10.771 & 18.341 & 25.648 & 23.991 & 192 & 315 & 859 & 1.283 \\
\hline Outros & 39.740 & 61.713 & 71.146 & 81.708 & 1.609 & 1.259 & 1.788 & 2.301 \\
\hline Exposição de crédito bruta & - & - & - & - & 2.036 & 2.672 & 3.256 & 3.859 \\
\hline
\end{tabular}

Fonte: BIS, Semiannual OTC derivatives statistics at end-June 2007.

Nota:a) Nas estatísticas do BIS, reporting dealers são os grandes bancos internacionais eos agentes chamados debroker-dealer nos Estados Unidos. Nenhuma outra instituição financeira não-bancária está incluída nessa rubrica.

foram assumidos, sobretudo, pelas instituições financeiras não-bancárias. Mas, o fato desses riscos terem sido transferidos não os anulou, eles permaneceram presentes no mesmo montante consolidado. Essa transferência de riscos significou apenas que eles deixaram de incidir no balanço da instituição que originou o crédito e passaram a ser de responsabilidade da outra instituição que constituiu a contraparte da operação. De forma agregada, as instituições financeiras do global shadow banking system passaram a ser as contrapartes dos bancos nessas operações uma vez que optaram por ter um acesso conside- 
[45] Bourguinat, H. La tyrannie des marchés: essai sur l'economie virtuelle. Paris: Economica, 1995.

[46] English, Simon. "Apocalypse is nigh, Buffett tells Berkshire faithful". The Daily Telegraph, 03/03/2003.

[47] Como sugerido por Blackburn (op. cit., p. 81): "os derivativos de crédito ajudaram a obnubilar as distinções entre os bancos comerciais e os de investimento". rado altamente remunerador às operações de crédito. Bastava captar recursos no mercado de títulos de curto prazo e adquirir os títulos de longo prazo com lastro em crédito e/ou assumir posições vendidas em proteção contra os riscos de crédito no mercado de derivativos para reproduzir "sinteticamente" uma operação de crédito. Dessa forma, os mercados de balcão tornaram-se o palco de negociação tanto de ativos como de passivos das instituições financeiras. Enquanto tal, eles se transformaram em fonte de funding e de investimentos para as instituições financeiras que deles participavam.

Foi a partir desta transferência de riscos pelos bancos que ocorreu o "milagre" de sua multiplicação. Nos casos em que esses riscos foram transferidos dos balanços dos bancos para outras instituições financeiras por meio de títulos securitizados e produtos estruturados, esses ativos foram "reempacotados" e deram origem a outros ativos que, por sua vez, foram vendidos a outras instituições. Enquanto estas operações se restringiram às transações no mercado à vista, eram os riscos originais que iam sendo trocados de mãos. Mas, ao serem acoplados aos derivativos de crédito, esses ativos deram origem a "ativos sintéticos", isto é, ativos que replicavam os riscos e retornos dos ativos originais, sem que fosse necessário possuí-los. Estes ativos "virtuais" 45 possuem tal propriedade porque negociam compromisso futuros de compra e venda de ativos, mediante o pagamento de um "sinal", o que abre a possibilidade de vender o que não se possui e/ou comprar o que não se deseja possuir. Nos mercados de balcão, multiplicaram-se as mais diversas combinações "virtuais" dos ativos de crédito securitizados com operações de derivativos de crédito. Os "produtos estruturados", que haviam permitido realizações de lucros recordes, se transformaram, para retomar a expressão do mesmo Warren Buffett, em "armas de destruição em massa" 46 .

$\mathrm{Na}$ construção dessa pirâmide, os riscos originais foram multiplicados por um fator $n$ e sua distribuição passou a constituir uma incógnita. Os riscos de crédito bancário, que saíram dos balanços dos bancos, transformaram-se em riscos de contraparte, dependentes da capacidade de pagamento dos agentes que os assumiram no conjunto da pirâmide.

A introdução e forte expansão nos mercados de balcão dos derivativos de crédito, isto é, a transformação de partes constitutivas dos ativos bancários em ativos negociáveis fez com que o sistema bancário e o global shadow banking system se interpenetrassem de modo quase inextrincável 47 . Os prejuízos das instituições participantes do global shadow banking system acabaram, em parte, achando seu caminho para os balanços dos bancos. Alguns bancos (por exemplo, o Citibank) tinham incluído opções de venda (que davam a seu detentor a possibilidade de revender o ativo a um preço predeterminado) nos títulos 
de securitização de crédito. Essas opções foram exercidas, obrigando os bancos a recomprar os ativos no momento em que sua liquidez desapareceu e seus preços tenderam a zero. Os diversos SIV tinham a garantia dos bancos patrocinadores. Em outros casos, esses novos intermediários possuíam linhas de crédito pré-aprovadas com bancos universais que foram amplamente utilizadas após a eclosão da crise.

Nos derivativos de crédito, além dos prejuízos ocasionados aos vendedores de proteção pela alta dos preços dos CDS, agregaramse, em primeiro lugar, os prejuízos decorrentes da concretização dos eventos de crédito incluídos nos contratos de CDS. Verificou-se que esta definição costumava ser muito ampla, incluindo, além de falência, necessidades de recapitalização. Isto fez com que a proteção conferida por CDS que tinham por ativo subjacente os títulos das GSE, dos bancos hipotecários e da AIG, por exemplo, fosse exercida, obrigando os vendedores de proteção a cumprir o compromisso assumido de efetuar o pagamento das somas predeterminadas aos que compraram esta proteção. Assim, em 6 de outubro de 2008 ocorreu a liquidação dos contratos vinculados às GSE num volume estimado entre US $\$$ 200 bilhões e US $\$ 500$ bilhões. Apesar das garantias do Tesouro, esta liquidação acabou gerando um prejuízo estimado entre US $\$ 2$ bilhões a US $\$ 5$ bilhões aos vendedores de proteção. A liquidação dos CDS atrelados ao Lehman Brothers no dia 10 de outubro foi geradora de prejuízos muito mais elevados, com pagamentos por parte dos vendedores de proteção estimados em mais de US $\$ 400$ bilhões.

Em segundo lugar, falta contabilizar os prejuízos decorrentes do risco de contraparte das instituições do global shadow banking system. Boa parte dessas instituições - que tinham assumido a contraparte dos riscos transferidos pelos bancos - não apresenta condições de honrar os compromissos assumidos que continuam crescendo num ritmo infernal. Seus credores, os bancos universais, tampouco têm condições de prescindir desses pagamentos. Enfim, o papel complexo e obscuro desempenhado por esse conjunto de instituições e pelos instrumentos financeiros negociados nos mercados de balcão multiplicaram os riscos e tornaram sua distribuição desconhecida. Isso dificulta e prolonga uma solução negociada para a crise.

\section{CONSIDERAÇÕES FINAIS}

Diante da magnitude das perdas e dos recursos públicos envolvidos na tentativa de se restabelecer a confiança, ficou evidente a fragilidade do sistema financeiro desregulamentado, liberalizado e supervisionado de forma displicente, que fomentou a expansão do global shadow bankingsystem. O resgate das agências hipotecárias (Fannie Mae e Freddie Mac) e da seguradora American Insurance Group (AIG), o
[48] Após divulgar uma queda em seus lucros trimestrais em $24 \%$, com o menor uso dos cartões e maior inadimplência dos clientes, a American Express passou a enfrentar dificuldades para emitir novos títulos de dívida e, portanto, para obter financiamento. Diante disso, o Federal Reserve aprovou sua conversão em banco comercial em 11 de novembro de 2008 . Com isso, a empresa poderá se beneficiar dos programas de financiamento de baixo custo da autoridade monetária. $\mathrm{O}$ mesmo ocorreu com o Banco da GM. Essas 
decisões podem representar o fim das empresas financeiras que operam em uma única linha de negócios e são dependentes dos mercados financeiros para obter financiamento.

[49] Guttmann, R. A primer on finance-led capitalism. Nova York: Hofstra University; Paris: CEPN, 2008 (submitted for Revue de la Regulation) [publicado nesta edição: "Uma introdução ao capitalismo dirigido pelas finanças". Trad. Hélio Mello Filho]; e Cintra, Marcos A. M. \& Prates, Daniela M. The financing of developing countries in the face of the global financial crisis. Paper preparado para o Workshop on Financial Liberalization and Global Governance: the Role of International Entities, Rio de Janeiro, 13 e 14 de novembro de 2008 . Evento organizado pelo IBase e pela Fundação Ford [Disponível em <www.ibase. org.br>, acessado em 24/11/2008].

[50]O relatório do Counterparty Risk Management Policy Group III (CRMPG III, 2008), por exemplo, recomendou: a) criação de uma câmara de compensação para os derivativos de balcão; b) exigências que as contrapartes em certas operações no mercado de balcão sejam "suficientemente sofisticadas para entender as operações e seus riscos"; c) mudanças na contabilização dos ativos lastreados em crédito incluindo os já existentes - que deixariam de ser considerados "fora de balanço" e passariam a ser incluídos nos balanços. Essa última recomendação provocaria um forte aumento do capital regulatório e obrigaria muitas instituições a captar elevados montantes de capital. Todavia, "por mais custosas que venham a ser essas reformas, esse custo será minúsculo se comparado às centenas de bilhões de dólares em créditos em liquidação que as instituições financeiras tiveram de enfrentar nos últimos meses, para não falar das distorções e dos deslocamentos econômicos ocasionados pela crise".

Recebido para publicação em 20 de novembro de 2008.

\section{NOVOS ESTUDOS}

CEBRAP

82 , novembro 2008

pp. 35-55 desaparecimento dos cinco grandes bancos de investimento de Wall Street (Bear Sterns, Lehman Brothers, Merril Lynch, Goldman Sachs, Morgan Stanley), a falência de diversos bancos hipotecários, de fundos de investimentos, de hedgefunds, de private equities funds aceleraram um processo de enxugamento desse gigantesco "sistema financeiro paralelo" que proliferou inovações cada vez mais complexas e opacas.

A quebra das instituições insolventes e o desaparecimento da liquidez dos instrumentos financeiros mais exóticos foram promovendo um acentuado processo de desalavancagem e uma reconfiguração forçada do sistema financeiro global ${ }^{8}$. Foi promovendo ainda um enquadramento das instituições sob a regulação e supervisão do Federal Reserve System e dos outros bancos centrais (Reino Unido, União Européia, Suíça, Japão, Canadá etc.). Todavia, o risco sistêmico de um desmoronamento do sistema financeiro como um todo tornou cada vez mais inevitável a adoção de um sistema mais abrangente de regulação e supervisão. Isso deverá implicar uma consolidação das diversas agências regulatórias, tanto na Europa como nos Estados Unidos. A crise revelou a obsolescência das estruturas de supervisão descentralizadas, dado o grau de imbricação entre as diversas instituições financeiras (bancos, fundos de pensão, seguradoras, fundos de investimento) e mercados (de crédito, de capitais e de derivativos). Destaca-se que essa questão já foi encaminhada pelo governo americano. Um dos pilares da proposta de reestruturação da estrutura regulatória do sistema financeiro dos Estados Unidos, encaminhada ao Congresso no final de março de 2008 , consistiu exatamente na consolidação das diversas agências reguladoras do país. Ademais, nessa proposta, o Federal Reserve teria poderes ampliados, passando a supervisionar, além das holdings financeiras, os bancos de investimento, seguradoras e fundos de investimento (inclusive hedge funds).

Dessa forma, as novas regras para o funcionamento dos sistemas financeiros parecem caminhar para um aperfeiçoamento do Acordo de Basiléia II em âmbito global, naquilo que vem sendo chamado de "auto-regulação supervisionada", com alguma regra sobre o grau de alavancagem, testes de estresse para novos instrumentos e governança corporativa que reflete as responsabilidades fiduciárias das instituições financeiras 49 . As instituições financeiras - internacionalmente ativas ou não - serão enquadradas nas normas de capital ponderado pelos riscos, nos sistemas de monitoramento e gestão de riscos cada vez mais sofisticados. Os mercados de derivativos de balcão, sobretudo, os derivativos de crédito, serão dotados de câmaras de compensaçãoso.

Marcos Antonio MaCedo Cintra é professor do IE/Unicamp e pesquisador do Conselho Nacional de Desenvolvimento Científico e Tecnológico (CNPq).

MARYSE FARH é professora do IE/Unicamp e pesquisadora do Centro de Conjuntura e Política Econômica (Cecon/IE/Unicamp). 